\title{
Nodule Bacteria Associated with the Indigenous Leguminosae of South-Western Australia
}

\author{
By R. T. LANGE \\ Institute of Agriculture, University of Western Australia, \\ Nedlands, Western Australia*
}

(Received 22 April 1961)

SUMMARY

Root-nodule bacteria (rhizobia) isolated in pure culture from legumes indigenous to south-western Australia were examined for cultural and infective characters. All isolated strains had cultural characters consistent with the slow-growing bacteria of the lupin or soybean type. None of the strains nodulated peas, clover or medic, but hosts from the other four recognized cross-inoculation groups were nodulated. Lupinus digitatus, Glycine hispida, Vigna sinensis and Phaseolus vulgaris formed a natural grouping on the basis of susceptibility to nodulation by the native strains. Within the narrower host range of the genus Lupinus it was found that L. digitatus, L. albus and $L$. pilosus grouped together on susceptibility to nodulation, whereas L. luteus, L. angustifolius and Ornithopus sativus were not nodulated by any of the sample strains. The use of this geographically isolated sample of rhizobia has further demonstrated the weakness of the present scheme of classification of the nodule bacteria, which is based on the infective character of the bacteria. A taxonomic system based on Adansonian principles could be applied to the classification of the rhizobia, and a procedure for attempting this is outlined.

\section{INTRODUCTION}

The genus Rhizobium comprises a group of organisms characterized by their ability to induce the formation of nodules on the roots of legumes. Allen \& Allen (1950) stated ' . . the ability to invade the roots of leguminous plants and stimulate the production of nodules... is the sole criterion for the existence of the genus Rhizobium'. Bacteria thus grouped on the feature of legume root nodulation are subgrouped on the range and type of host plants infected. Bergey's Manual (1957) accords six of these subgroups specific status but appends a note that some of them may be related. While this classification is generally recognized as imperfect, it persists in the absence of a better system. The present paper reports some results from a survey of the rhizobia associated with indigenous legumes of the botanical South-West Province of Western Australia (Lange, 1960). The province itself is about 100,000 square miles in area. Its climate was discussed by Gentilli (1946), its geomorphology by Jutson (1950), soils by Teakle (1938) and the indigenous vegetation by Diels (1906) and Gardner (1942). Indigenous Leguminosae total over 400 species in about 35 genera of the Caesalpiniaceae, Mimosaceae and Papilionaceae. A great many of the species are endemic to the area. Nearly half are species of

* Now at Department of Botany, University of Adelaide, South Australia. 
Acacia; the remainder are mostly papilionaceous, principally in genera of the tribe Podalyrieae. The incidence of nodulation in these indigenous legumes has already been tabulated (Lange, 1959).

\section{METHODS}

Over a 2-year period, $\mathbf{7 0 0 0}$ miles of traverses were made throughout the study area and the vegetation examined at intervals, usually of only a few miles. Leguminous species were collected for identification and examined for root-nodulation. Species representative of the indigenous Leguminosae were selected from those found to be nodulated. Nodules were removed from these plants in the field, and desiccated in tubes over anhydrous $\mathrm{CaCl}_{2}$ (Dr D. O. Norris, personal communication). In the laboratory the nodules were reconstituted by soaking in sterile water. They were then surface-disinfected by immersion for $15 \mathrm{~min}$. in a mixture of equal volumes of $\mathrm{H}_{2} \mathrm{O}_{2}$ (100 vol.) and absolute ethanol, washed and macerated. Samples were streaked on plates of yeast extract + mannitol agar and incubated at $27^{\circ}$.

One hundred and sixty-three strains of presumptive rhizobia were isolated in pure culture. Eighty-five of these isolates from 83 host species in 24 legume genera were selected as a fair sample of the Rhizobium population associated with indigenous Leguminosae in the area (see Table 1).

Two series of tests were applied to the sample strains.

\section{Tests of cultural characters}

Colony characters. Visible characteristics of colonies on isolation plates and in pure culture were recorded. Strains of known performance from Glycine, Lathyrus Trifolium, Medicago, Phaseolus and Lupinus were included in all tests to allow direct comparisons to be made.

Morphology and staining. Preparations from 6-day-old cultures were stained by Gram's method and with carbol rose bengal and examined.

Calcium glycerophosphate medium. Strains were streaked on slopes of calcium glycerophosphate agar (Hofer, 1941), incubated for 3 weeks at $27^{\circ}$ and observed for browning of the medium.

Litmus milk. Strains were inoculated into sterile litmus milk, incubated for 4 weeks at $27^{\circ}$ and observed for $\mathrm{pH}$ change and for serum zone formation.

Colony growth rate. Strains were dispersed in sterile water and dilution series made. Drops of appropriate dilutions were spread over yeast extract + mannitol agar plates to yield ten to thirty well-isolated colonies. Each plate was incubated at $27^{\circ}$, inspected daily, and the times for half of the colonies in sector areas to reach diameters of $1 \mathrm{~mm}$. recorded.

Reactions on sugar. Cultures were inoculated on to nitrate agar medium (Baldwin \& Fred, 1927) containing either arabinose, rhamnose, xylose, maltose or sucrose, and $\mathrm{pH}$ changes observed after incubation for 5 weeks at $27^{\circ}$.

\section{Tests of infectiveness on legumes}

Each of the 85 sample strains was further investigated in a series of glasshouse experiments to determine its infectiveness on the following legumes: Pisum sativum L., Lathyrus cicera L., Lens esculenta Moench., Vicia sativa L., Lupinus angustifolius L., L. luteus, L., L. nanus Dougl., L. digitatus Forsk., L. albus L., L. pilosus Murr., 
L. villosus Willd., L. subcarnosus Hook., Ornithopus sativus Brot., O. compressus L., Medicago tribuloides Desr.,. Trifolium subterraneum L., Vigna sinensis Engl., Phaseolus vulgaris L., P. lathyroides $\mathbf{L}$., and Glycine hispida Maxim. These include hosts from the seven major cross-inoculation groups. The eight Lupinus species were included since it had been indicated earlier that lupins may be differentially susceptible to native rhizobia in the area (Adams \& Riches, 1930; Lange \& Parker, 1960). The following conditions were imposed during the course of the experiments.

(1) Strains known to be infective on the hosts were included. These invariably nodulated the host legume under the conditions of experiment. This ensured that experimental conditions did not restrict nodulation of the plant.

(2) Experiments were terminated when the control nodulation was fully established.

(3) Control uninoculated plants were included at a frequency of $20 \%$ of inoculated plants.

(4) Conditions for plant growth were kept as close to optimal as possible.

Experiments were conducted in closed glasshouse rooms with adequate sunlight and pressurized by air coolers delivering washed air. The rooms were sprayed down completely with insecticidal, fungicidal and bactericidal sprays, and with paraffin oil emulsion (25\% paraffin oil). Dust immobilization was maintained by further spraying with paraffin oil emulsion containing antibacterial substances. Large plants were grown in open sand-filled porous drainage pots spaced on slatted bench tops over an area heavily coated with paraffin oil emulsion. Pots were dressed with a nitrogen-deficient nutrient solution providing major and minor elements. Superphosphate was mixed with the sand separately at the rate of 300 p.p.m. as the fertilizer. Trifolium and Medicago plants were grown in agar tubes after the method of Chen \& Thornton (1940).

Pots were brought to field capacity, wrapped, stacked in a bin and subjected to a continuous flow of steam for $1 \mathrm{hr}$; this raised the temperature of the sand to at least $90^{\circ}$. Seeds were disinfected by immersion for 10-20 min. in a mixture of equal volumes of 100 vol. $\mathrm{H}_{2} \mathrm{O}_{2}$ and absolute ethanol, followed by washing in sterile water. The seeds were then germinated and planted under sterile conditions. Inoculum was applied direct to the seed coat, and pots were watered with sterile water. The tests were completed in a total of twelve experiments, each of factorial design: host. species $\times$ sample strains $\times$ a minimum of four replications.

Root systems were washed out usually about 28 days after germination and floated in water for examination. In one experiment nodulation occurred in some of the uninoculated control plants; this experiment was repeated. In the experiments reported here the control of nodulation was absolute.

\section{RESULTS}

\section{Cultural characters}

All 85 bacterial strains originated from within the tissues of sound legume rootnodules and grew as aerobic heterotrophs. Colonies after 8 days were punctiform, rarely exceeding $1 \mathrm{~mm}$. diam., and were opaque or rarely translucent, whitish, and gummy. No isolated colony exceeded punctiform size within $\mathbf{5}$ days, and all strains were therefore slow-growing compared to the known strains of Rhizobium meliloti, 
354 Table 1. The infectiveness of 85 strains of nodule bacteria on 9 legume

\section{test hosts}

+ , Nodulation on all plant replications; \pm , nodulation on some but not all plants; - , complete absence of nodulation.

Host nodulated

Host of isolation

Acacia acuminata Benth. ericifolia Benth. stenoptera Benth. erinacea Benth. extensa Lindl.

Drummondii Lindl. myrtifolia Willd. cyanophylla Lindl. hastulata Smith horridula Meissn. nervosa D.C. volubilis F.v.M. pulchella R.Br. diptera Lindl.

Albizzia distachya (Vent.) Macbride

Aotus villosa $\mathrm{Sm}$.

Preissii Meissn.

Tietkinsii F.v.M.

Bossiaea Presii Meissn.

Laidlawiana Tovey

et Morris

Webbii F.v.M.

dentata Benth.

aquifolium Benth.

eriocarpa (R.Br.)

Benth.

linophylla R.Br.

Brachysema lanceolatum

$$
\begin{aligned}
& \text { Meissn. } \\
& \text { sericeum (Sm.) } \\
& \text { Domin. } \\
& \text { praemorsum } \\
& \text { Meissn. }
\end{aligned}
$$

Chorizema Dicksonii Grah. ilicifolium Labill. reticulatum

Meissn.

aciculare (D.C.)

C.A. Gardn.

cytisoides Turcz. 119

ericifolium Meissn. $\quad 52$

Davesia hakeoides Meissn. $\quad 57$ brevifolia Lindl. $\quad 101$

pectinata Lindl. sphylla (F.v.M.) Benth.

incrassata $\mathrm{Sm}$.

Dillwynia uncinata (Turcz.)

C.A. Gardn.

Euchilopsis linearis (Benth.) F.v.M.

90

123

122

120

\begin{tabular}{|c|c|c|c|c|c|c|c|c|c|}
\hline $\begin{array}{c}\text { Strain } \\
\text { no. }\end{array}$ & $\begin{array}{c}\text { Gly- } \\
\text { cine } \\
\text { hispida }\end{array}$ & $\begin{array}{c}\text { Lupi- } \\
\text { nus } \\
\text { albus }\end{array}$ & $\begin{array}{c}\text { L. } \\
\text { digi- } \\
\text { tatus }\end{array}$ & $\underset{\text { pilosus }}{\text { L. }}$ & $\begin{array}{c}L . \\
\text { subcar- } \\
\text { nosus }\end{array}$ & $\begin{array}{l}\text { L. vil- } \\
\text { losus }\end{array}$ & $\begin{array}{c}\text { Phase- } \\
\text { olus } \\
\text { lathy- } \\
\text { roides }\end{array}$ & $\begin{array}{c}P . \\
\text { vul- } \\
\text { garis }\end{array}$ & $\begin{array}{c}\text { Vigna } \\
\text { sin- } \\
\text { ensis }\end{array}$ \\
\hline
\end{tabular}

$\begin{array}{lll}+ & \pm & + \\ + & \pm & + \\ + & + & + \\ \pm & \pm & \pm \\ + & \pm & + \\ \pm & \pm & \pm \\ + & \pm & + \\ \pm & \pm & + \\ \pm & - & + \\ + & \pm & + \\ + & + & + \\ - & \pm & + \\ - & \pm & + \\ + & \pm & + \\ + & \pm & +\end{array}$
,$$
\begin{array}{ll} 
\pm & - \\
+ & - \\
+ & \pm \\
\pm & - \\
+ & \pm \\
\pm & - \\
+ & - \\
+ & + \\
+ & - \\
+ & - \\
+ & \pm \\
+ & \pm \\
+ & \pm \\
+ & - \\
+ & -
\end{array}
$$$$
\begin{array}{lll}
- & - & + \\
- & - & + \\
- & - & + \\
- & - & \pm \\
- & - & + \\
- & - & \pm \\
- & - & + \\
- & - & \pm \\
- & - & \pm \\
- & - & + \\
- & - & + \\
- & - & - \\
- & - & - \\
- & - & + \\
- & - & +
\end{array}
$$$$
\begin{aligned}
& + \\
& + \\
& + \\
& \pm \\
& + \\
& \pm \\
& + \\
& + \\
& + \\
& + \\
& + \\
& + \\
& + \\
& + \\
& +
\end{aligned}
$$$$
- \pm
$$$$
+
$$$$
- \pm
$$$$
+
$$$$
- \pm \pm \pm
$$$$
\begin{aligned}
& \pm \\
& \pm \\
& -
\end{aligned}
$$

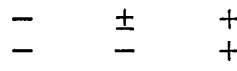$$
\pm \quad+
$$$$
+
$$ 
Host of isolation

Eutaxia epacridioides

Meissn.

virgata Benth.

densifolia Turcz.

Gastrolobium villosum Benth. 106 spinosum Benth. 61 obovatum Benth. 32 trilobum Benth. 100

Gompholobium marginatum $\quad 60$

$$
\text { R.Br. }
$$

venustum R.Br. 66 polymorphum 111

R.Br.

Knightianum 108

Lindl.

tomentosum

Labill.

Hardenbergia Comptoniana $\quad 19$

(Andr.) Benth.

Hovea elliptica D.C.

trisperma Benth.

chorizemifolia D.C. pungens Benth.

104

Strain cine $\begin{array}{cc}\text { Gly- } & \text { nupi- } \\ \text { cine } & \end{array}$

no. hispida albus

87

105

37

Phase-

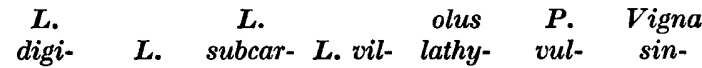
tatus pilosus nosus losus roides garis ensis

$\begin{array}{ccccccccc}+ & - & + & - & - & - & + & + & + \\ - & \pm & + & - & - & - & + & + & + \\ - & - & - & \pm & - & - & \pm & + & \pm \\ - & - & + & - & - & - & \pm & \pm & + \\ - & + & + & \pm & - & - & + & - & + \\ - & \pm & \pm & - & - & - & \pm & \pm & + \\ + & - & + & - & - & - & + & + & + \\ + & - & + & - & - & - & \pm & \pm & +\end{array}$

Isotropis cuneifolia (Sm.)

Domin.

Jacksonia hakeoides Meissn. $\quad 69$ spinosa (Labill.) 102

R.Br.

horrida D.C. 33

furcellata (Bonpl.) 125

D.C.

Kennedya eximia Lindl. $\quad 73$

coccinea Vent. $\quad 77$

Stirlingii Lindl. $\quad 78$

prostrata $\mathrm{R.Br}$. 2

Stirlingii Lindl. $\quad \mathbf{7 6}$

Latrobea hirtella (Turcz.) 133

Mirbelia floribunda Benth. $\quad 89$

spinosa Benth. $\quad 127$

dilatata R.Br. $\quad \mathbf{8 6}$

Oxylobium parviflorum Benth. 27

lanceolatum Benth. 130

capitatum Benth. 17

atropurpureum $\quad 141$

Turcz.

reticulatum Meissn. 81

Pultenaea reticulata (Sm.) 84

Benth.

strobilifera Meissn. $\quad 85$

ochreata Meissn. $\quad 94$

Sphaerolobium alatum Benth. $\quad 59$

medium R.Br. 128

grandiflorum 116

R.Br.

Templetonia retusa $\mathbf{R} . \mathrm{Br}$.

21

Viminaria denudata (Sm.)

93 
$\boldsymbol{R}$. trifolii and $\boldsymbol{R}$. leguminosarum which were included. All strains were Gramnegative. None exhibited spores or morphologically distinctive forms, but ranged from coccobacilli to more or less straight bacilli from 0.5 to $4.5 \mu$ by $0.5 \mu$. On calcium glycerophosphate agar all failed to cause browning. In litmus milk, all strains produced an alkaline reaction without appreciable dye reduction. None produced a serum zone. All 85 strains produced acid on arabinose and xylose, an acid reaction or no change of $\mathrm{pH}$ value on rhamnose, and alkaline reactions on maltose and sucrose.

\section{Infectiveness}

Under the conditions of the experiments, none of the 85 strains nodulated Pisum sativum, Lathyrus cicera, Lens esculenta, Vicia sativa, Lupinus angustifolius, $L$. luteus, L. nanus, Ornithopus sativus, O. compressus, Medicago tribuloides, or Trifolium subterraneum. The following plant species were nodulated by sample strains: Vigna sinensis (79 strains); Phaseolus vulgaris (76); Lupinus digitatus (71); Phaseolus lathyroides (67); Glycine hispida (53); Lupinus albus (47); L. pilosus (31); L. villosus (5) and L. subcarnosus (1). The details of their infective performance on these species are presented in Table 1.

\section{DISCUSSION}

Breaches of the cross-inoculation boundaries between the soybean and the cowpea (Leonard, 1923), and between lupins, soybeans and cowpea (Bushnell \& Sarles, 1937) have been reported before. The results submitted here further illustrate the deficiencies of the cross-inoculation-group concept when used to delineate species of Rhizobium. The bacterial strains used in this study were selected as representative of the microsymbionts from indigenous legumes in the study area. When compared with recognized Rhizobium species on the basis of their in vitro characters, all of them showed the characteristics of the slow-growing species Rhizobium japonicum, or of the cowpea group of rhizobia.

The range of infective performance exhibited by the sample strains extended to hosts from four of the recognized cross-inoculation groups, namely, the cowpea, lupin, soybean and bean groups. However, infection across the boundaries of these four groups was prevalent to the extent of being typical rather than exceptional. Thus of the 85 strains examined

\section{5 strains nodulated hosts in 4 cross-inoculation groups; 31 strains nodulated hosts in 3 cross-inoculation groups; 6 strains nodulated hosts in 2 cross-inoculation groups; \\ 3 strains nodulated hosts in 1 cross-inoculation group.}

On the evidence it is impossible to place these strains in specific cross-inoculation groups, or to assign species designations to them on the basis of the accepted system. Distinctly different host groupings are apparent. For example, Lupinus digitatus, Glycine hispida, Vigna sinensis and Phaseolus vulgaris group together on susceptibility to infection by the sample strains, even though these hosts are from four different cross-inoculation groups. Similarly, L. digitatus, L. albus and L. pilosus group with each other on susceptibility, but do not group at all with their accepted cross-inoculation associates $L$. angustifolius, L. luteus and Ornithopus sativus.

Three Rhizobium species were not involved at all. None of the data implicated the clover, the medic or the pea cross-inoculation groups in any way, although 
evidence from other sources (Kleczkowska, Nutman \& Bond, 1944; Norris, 1959) shows that the pea and clover groups are not as discrete as they were once regarded.

Past studies of root-nodule bacteria show preoccupation with symbiont infectiveness patterns because of the economic importance attached to them. For the same reason, there has been a further preoccupation with agronomic legumes. This bias has dominated microsymbiont classification. In the period around 1920 there were two conflicting approaches. On the one hand, an expedient classification of the bacteria was derived based solely on their segregations in symbiotic infectiveness patterns (Garman \& Didlake, 1914). On the other hand, the practice of classifying strains on the basis of symbiotic performance alone was rejected by Löhnis \& Hansen (1921). Literature published over the succeeding period recorded the continued dominance and development of the former approach (Fred, Baldwin \& McCoy, 1932). A species of Rhizobium was recognized as containing those microsymbionts which would nodulate a particular group of legumes. Other characters of the bacteria were not accorded equivalent taxonomic weight. Subsequently, patterns of symbiotic infectiveness were demonstrated to be less discrete (Leonard, 1923; Sears \& Clark, 1930; Raju, 1936; Bushnell \& Sarles, 1937). Interrelationships led some authors to suggest consolidations of groups and of species (Walker \& Brown, 1935), whilst others suggested retention of the old groups with provision for special cases (Allen \& Allen, 1936).

A second and very emphatic rejection of the cross-inoculation basis of strain classification was made by Wilson (1939) who produced substantial data to support his contentions. Further demonstrations of the inadequacies of the crossinoculation groups continued (Appleman \& Sears, 1942; Johnson \& Allen, 1952; Ishizawa, 1954; Bowen, 1960). Recently a third rejection of the cross-inoculationgroup concept was made. Norris (1956) considered that there was no satisfactory known basis for the subdivision of the rhizobia into species. He suggested the use of a symbiotic rating which would indicate the relative affinities of a particular strain for hosts within the three subfamilies of the Leguminoseae.

The suggested modifications all continue to classify the nodule bacteria on the basis of their infective performance, excluding comparisons with bacteria which cannot produce nodules on the roots of a legume. This is clearly unsatisfactory. To be effective as a classification of bacteria, a system should be erected on non-biased over-all similarities. The Adansonian classification proposed by Sneath (1957) fulfils these requirements. The classification of the root nodule bacteria might thus be resolved by research within the following stages:

(1) Collection of types (or neotypes) of all recognized Rhizobium species.

(2) Collection from botanically representative and geographically diverse sources the widest sample of legume root-nodule bacteria possible within research resources.

(3) Collection of types and representatives of possibly related bacteria, e.g. Agrobacterium (Hofer, 1941 ; Bonnier, 1953); Bacillus (Bisset, 1952, 1959); Beijerinckia (Derx, 1953).

(4) Derivation of a range of tests by which all these bacteria may be described.

(5) Application of the tests, and classification of all strains on the results, by Sneath's (1957) method.

By thus relating a full range of root-nodule bacteria to each other and to other bacteria, their over-all similarities and groupings should become evident, and the 
genus Rhizobium with its component species could be retained or rejected. Application of an Adansonian classification to the strains used in this study would be premature, since both the strain sample and the test range are not adequate for the derivation of a generalized classification.

This work was carried out during the tenure of C.S.I.R.O. Post-graduate Studentships, and was financed by the Western Australian Wheat Industry Research Fund and by University of Western Australia Research Grants. I wish to express my thanks to my supervisor Dr C. A. Parker for his guidance and assistance throughout the study; to Mr C. Boundy of the Division of Mathematical Statistics, C.S.I.R.O., for the statistical analysis of the original data and for helpful discussions on the use of the Adansonian method; to Mr R. D. Royce, Curator of the State Herbarium, for his generous assistance in the identification of plant specimens, and to Professor E. J. Underwood, Director of this Institute, for his support and encouragement.

\section{REFERENCES}

Adams, A. B. \& Rrches, J. H. (1930). Root nodules on lupins. J. Dept. Agric. W. Aust. series 2, 7, 556 .

Allen, E. K. \& Allen, O. N. (1950). Biochemical and symbiotic properties of the rhizobia. Bact. Rev. 14, 273.

Allen, O. N. \& Allen, E. K. (1036). Root nodule bacteria of some tropical leguminous plants. I. Cross-inoculation studies with Vigna sinensis L. Soil Sci. 42, 61.

Appleman, M.D. \& Sears, O. H. (1942). Further evidence of interchangeability among the groups of Rhizobium leguminosarum. Soil Sci. Soc. Amer. Proc. 7, 263.

Baldwin, I. L. \& Fred, E. B. (1927). The fermentation characters of the root nodule bacteria of the Leguminosae. Soil Sci. 24, 217.

Bergey's Manual of Determinative Bacteriology (1957). 7th ed. Ed. Breed, R. S., Murray, E. G. D. and Smith, N. R. Baltimore, U.S.A.: Williams and Wilkins Co.

Bisset, K. A. (1952). Complete and reduced life cycles in Rhizobium. J. gen. Microbiol. 20, 233.

BIsSEt, K. A. (1959). Some characters of Rhizobium strains from tropical legumes. $J$. gen. Microbiol. 20, 89.

Bonnier, C. (1953). Classification et spécificité de l'hôte dans le genre Rhizobium. Proc. VIth int. Congr. Microbiol. 6, 325.

Bowen, G. D. (1960). Specificity and nitrogen fixation in the Rhizobium symbiosis of Centrosema pubescens Biult. Qd J. agric. Sci. 16, 267.

Bushneld, O. A. \& SARLEs, W. B. (1937). Studies on the root-nodule bacteria of wild leguminous plants in Wisconsin. Soil Sci. 44, 409.

Chen, H. K. \& Thonnton, H. G. (1940). The structure of ineffective nodules and its influence on nitrogen fixation. Proc. Roy. Soc. B, 129, 208.

Derx, H. G. (1953). Sur les causes de la distribution géographique limitée des Beijerinckia. Proc. VIth int. Congr. Microbiol. 6, 354.

Diels, L. (1906). Die Pflanzenwelt von Western Australien, in Die Vegetation der Erde. Ed. A. Engler \& O. Drude. Leipzig: Wilhelm Engelmann.

Fred, E. B., Baldwin, I. L. \& McCoy, E. (1932). Root nodule bacteria and leguminous plants. Univ. Wis. Stud. Sci. 5, 343.

Gardner, C. A. (1942). The vegetation of Western Australia with special feference to the climate and soils. J. roy. Soc. W. Aust. 28, xi.

Garman, H. \& Didlake, M. (1914). Six different species of nodule bacteria. Bull. $K y$. agric. Exp. Sta. 184.

Gentilli, J. (1946). Australian Climates and Resources. Melbourne: Whitcombe and Tombs.

HoFer, A. W. (1941). A characterization of Bacterium radiobacter (Beijerinck and van Delden) Löhnis. J. Bact. 41, 193. 
Ishizawa, S. (1954). Studies on the root-nodule bacteria of leguminous plants. J. Sci. Soil, Tokyo, 24, 249.

Johnson, M. D. \& Allen, O. N. (1952). Nodulation studies with special reference to strains isolated from Sesbania species. Antonie van Leeurvenhoek J. Microbiol. Serol. 18, 12.

Jutson, J. T. (1950). The physiography (geomorphology) of Western Australia. Bull. geol. Surv. W. Aust. 95. Perth: Government Printer.

KLeczKowska, J., Nutman, P. S. \& Bond, G. (1944). Note on the ability of certain strains of rhizobia from peas and clover to infect each other's host plants. J. Bact. 48, 673.

LANGe, R. T. (1959). Additions to the known nodulating species of Leguminoseae. Antonie van Leeuwenhoeck J. Microbiol. Serol. 25, 272.

LANGE, R. T. (1960). The occurrence, characteristics and classification of Rhizobium associated with indigenous Leguminoseae in South-Western Australia. Ph.D. Thesis, University of Western Australia, 203 pp.

LANGe, R. T. \& Parker, C. A. (1960). The symbiotic performance of lupin bacteria under glasshouse and field conditions. Plant \& Soil, 13, 137.

LEONARD, L. T. (1923). Nodule production kinship between the soybean and the cowpea. Soil Sci. 15, 227.

Löhnis, F. \& Hansen, R. (1921). The nodule bacteria of leguminous plants. J. agric. Res. (U.S.), 20, 543.

Norris, D. O. (1956). Legumes and the Rhizobium symbiosis. Emp. J. exp. Agric. 24, 247.

Norris, D. O. (1959). Rhizobium affinities of African species of Trifolium. Emp. J. exp. Agric. 27, 87.

RAJU, M. S. (1936). Studies on the bacterial-plant groups of cowpea, cicer and dhaincha. I. Classification. Z Zbl. Bakt. II. 94, 249.

SEARs, O. H. \& ClARK, F. M. (1930). Non-reciprocal cross-inoculation of legume nodule bacteria. Soil Sci. 30, 237.

SNeath, P. H. A. (1957). The application of computers to taxonomy. J. gen. Microbiol. 17, 201.

Teakle, L. J. H. (1938). A regional classification of the soils of Western Australia. J. roy. Soc. W. Aust. 24, 123.

Walker, R. H. \& Brown, P. E. (1935). The nomenclature of the cowpea group of root nodule bacteria. Soil Sci. 39, 221.

Wirson, J. K. (1939). Leguminous plants and their associated organisms. Mem. Cornell agric. Exp. Sta. 221. 